\title{
Regulatory T cells in embryo implantation and the immune response to pregnancy
}

\author{
Sarah A. Robertson, Alison S. Care, and Lachlan M. Moldenhauer \\ Robinson Research Institute and Adelaide Medical School, University of Adelaide, Adelaide, South Australia, Australia.
}

\begin{abstract}
At implantation, the embryo expresses paternally derived alloantigens and evokes inflammation that can threaten reproductive success. To ensure a robust placenta and sustainable pregnancy, an active state of maternal immune tolerance mediated by $\mathrm{CD}^{+}$regulatory $\mathrm{T}$ cells (Tregs) is essential. Tregs operate to inhibit effector immunity, contain inflammation, and support maternal vascular adaptations, thereby facilitating trophoblast invasion and placental access to the maternal blood supply. Insufficient Treg numbers or inadequate functional competence are implicated in idiopathic infertility and recurrent miscarriage as well as later-onset pregnancy complications stemming from placental insufficiency, including preeclampsia and fetal growth restriction. In this Review, we summarize the mechanisms acting in the conception environment to drive the Treg response and discuss prospects for targeting the T cell compartment to alleviate immune-based reproductive disorders.
\end{abstract}

\section{Introduction}

Within days of conception, the embryo attaches to the uterine lining, and trophoblast cells invade into the uterine decidua (1). A finely controlled developmental program then unfolds, with successive waves of trophoblast invasion, proliferation, and differentiation to form a mature placenta that sustains fetal growth throughout gestation.

This remarkable feat occurs in apparent defiance of the mother's immune response. Abundant immune cells reside in the decidua in close contact with infiltrating trophoblasts, and paternally derived alloantigens are expressed in the developing placental and fetal tissues. Far from the immune evasion or systemic immune suppression historically invoked to explain maternal-fetal tolerance (2), maternal immune cells exhibit priming toward fetal alloantigens (3-5) and actively participate in many aspects of establishing, sustaining, and terminating pregnancy (6).

Mammalian pregnancy cannot be readily reconciled with the classical self/non-self discrimination theory or alternative models of immune regulation (7). Central tolerance, wherein self-reactive lymphocytes are deleted in the thymus (8), is not relevant, since fetal alloantigens are not encountered outside of the reproductive context. Instead, a range of specialized mechanisms in both the innate and adaptive immune compartments mediate an active state of functional tolerance that permits fetal and maternal cells to coexist. Key suppressive mechanisms include attenuated placental expression of polymorphic MHC molecules $(9,10)$; placental release of antiinflammatory and protolerogenic hormones, cytokines, and immune modulatory molecules (11-13); and specialized decid-

Conflict of interest: SAR is an inventor on international patent PCT/AU99/00499 and receives royalty income from Origio A/S. SAR and LMM receive research support from Ferring Pharmaceuticals (US)

Reference information: J Clin Invest. 2018;128(10):4224-4235.

https://doi.org/10.1172/JCI122182. ual regulation of immune cell access and egress (refs. 14, 15, and for additional information, see refs. 6, 16-18).

There is a strong imperative to define how pregnancy tolerance is established, as an immune etiology is implicated in common reproductive conditions including recurrent implantation failure and miscarriage (19-21), as well as later-onset gestational disorders that arise as a result of disturbed implantation and placental morphogenesis (22-24). Recurrent implantation failure occurs when overtly healthy embryos fail to implant normally and is the cause of infertility in approximately $10 \%$ of women seeking in vitro fertilization (IVF) treatment (25). Recurrent pregnancy loss, defined as loss of three or more karyotypically normal embryos before 20 weeks' gestation, occurs in approximately $1 \%$ to $2 \%$ of women (26). Preeclampsia affects $3 \%$ to $5 \%$ of pregnancies (27) and is a major cause of morbidity and mortality for women and infants, particularly in low- and middleincome countries, and it is often accompanied by fetal growth restriction and preterm birth $(28,29)$.

Tolerance arises in the preimplantation phase of early pregnancy and appears to require a unique dialog involving maternal-, paternal-, and conceptus-derived signals and specialized anatomical elements of the reproductive tissues $(30,31)$. Their interaction drives a cascade of immune changes that initiate prior to conception, persist through gestation, and culminate with birth $(6,18)$. Innate immune cells, particularly macrophages (32), DCs (33), and a unique population of NK cells with a CD56 ${ }^{\text {hi }} \mathrm{CD} 57^{\text {lo }}$ phenotype (uterine NK cells, or uNK cells) (34), are abundant in the decidua in the luteal phase of the menstrual cycle when implantation commences. These cells influence placental development through immune regulation, provision of growth factors, and facilitation of adaptations in the uterine vasculature to support trophoblast invasion. Innate immune cells exhibit altered phenotypes and contribute to pathophysiological processes in many gestational conditions (refs. 35, 36, and for more information, see refs. $17,37,38$ ). 


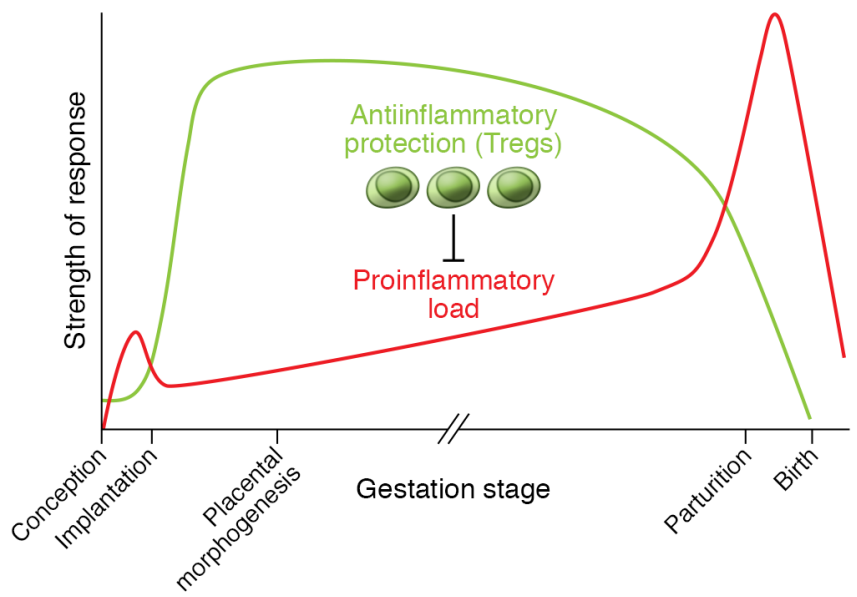

The adaptive immune response is also critical to pregnancy tolerance (refs. 39-41 and for more information, see refs. 18, 42), and an imbalance of $\mathrm{T}$ regulatory cells (Tregs) and effector $\mathrm{T}$ cells (Teffs) is emerging as a key underpinning factor in common fertility and obstetric disorders (19-21, 23, 24). Tregs are well known for their capacity to limit excessive inflammation and recalibrate tissue homeostasis after insult or injury, as well as to suppress Teff reactions to self or non-self antigens $(43,44)$. Tregs exert potent antiinflammatory, immune-regulatory, and vaso-regulatory functions (43-45) relevant to establishing pregnancy. Also significant is their distinct phenotypic plasticity, or capacity to transdifferentiate into Th17 cells $(46,47)$, which provides a potential mechanism for strategic female reproductive investment (48).

In women, T cells comprise $10 \%$ to $20 \%$ of decidual immune cells in the first trimester (49). Many of these are $\mathrm{CD} 8^{+} \mathrm{T}$ cells, including regulatory subsets $(50,51)$. Among the $\mathrm{CD}^{+} \mathrm{T}$ cells, approximately $10 \%$ to $30 \%$ express the Treg transcription factor FOXP3, which constitutes a substantial enrichment compared with its expression in peripheral blood (52-54). Decidual Th1 cell frequencies are moderately elevated, while Th17 and Th2 cells are generally not enriched, indicating a mild inflammatory environment controlled by Tregs $(53,55)$. The Tregs are composed of both thymus-derived Tregs (tTregs) and peripheral Tregs (pTregs) and exhibit phenotypic heterogeneity according to the cycle and pregnancy phase (36, $56,57)$. Uterine recruitment of Tregs in preparation for conception commences in the proliferative phase of each cycle, with an estrogen-driven increase peaking at ovulation (58). After increasing in early pregnancy, decidual Tregs remain elevated through mid-gestation before declining prior to birth $(52,53,59)$, with peripheral blood Tregs following a broadly similar pattern $(60,61)$.

In reproductive disorders, insufficient numbers of Tregs or impaired function is a common feature $(19,20,23)$, with a counteractive increase in Teffs $(21,24)$. Compelling evidence that Treg deficiency is causal in pregnancy loss comes from animal models (39, 62-64). An underlying T cell etiology in women is supported by correlations with prior sexual and reproductive history (65) and by couple-specific, HLA-linked dispositions to reproductive conditions (66-68), consistent with a protective effect of adaptive immune "memory" for partner histocompatibility antigens.

In this Review, we describe the current understanding of Tregs as master regulators of pregnancy tolerance, focusing on
Figure 1. Tregs are critical for controlling inflammation in the transition to an antiinflammatory decidual environment necessary for embryo implantation and progression of pregnancy. Mouse models show that Tregs act to suppress inflammation, prevent adverse effects of antifetal alloantigen Teff cells, and allow vascular adaptations required for placental morphogenesis $(39,41,62,63,82,87)$. Tregs arise as a consequence of events during the inflammation-like response in the periconception phase, and their abundance, suppressive function, and stability are impacted by events at conception and in the preimplantation phase $(39,83-85,135,137)$. Tregs sustain an antiinflammatory environment until a decline, associated with the inflammation events of parturition and birth, is triggered $(40,64$, $88,89)$. Decidual Tregs in pregnant women show kinetics and regulatory mechanisms comparable to those in mice ( $36,52-54,56,58,59)$. Recurrent implantation failure, recurrent miscarriage, preeclampsia, and in utero growth restriction are all linked with insufficient numbers, reduced suppressive function and/or instability of Tregs (19-21, 23, 24), and excessive inflammation in the uterus and/or gestational tissues $(21,27,80)$.

events surrounding conception that critically impact the availability and function of Tregs for implantation and later gestation. We explain the evidence for Tregs in the pathophysiology of infertility and obstetric disorders, discuss the origins of Treg deficiency in some women, and speculate on the prospect of targeting Tregs to address common reproductive and obstetric conditions.

\section{The immune response and embryo implantation}

Normal fetal growth depends on establishing a robust placenta to nurture the fetus; remarkably, two-thirds of genetic mutations identified as embryonically lethal in mice affect placental morphogenesis (69). Even minor derangement of the developmental program of the placenta can cause later miscarriage or set a trajectory toward preeclampsia $(22,27,70)$. These conditions can be traced back to aberrant interactions between trophoblasts and the uterine decidua at conception and implantation (70-72).

Critical to implantation is an adequate decidual response. Immune cells are instrumental, with reciprocal interactions between DCs, uNK cells, and invading trophoblasts $(73,74)$ in response to hormonal triggers to transform the uterine lining in the luteal phase $(1,71,72)$. Extensive contact between trophoblasts and immune cells in the decidua is common to all placental mammals (75) but is most conspicuous with invasive hemochorial placentation, as occurs in mice and humans (17). A sufficient number of decidual immune cells must acquire appropriate phenotypes to support the decidual response and remodel the local vascular network for embryo attachment and implantation $(71,76)$.

Leukocyte recruitment builds during the estrogen-dominated periovulatory phase, and a threshold level of inflammatory activation may facilitate the generation of a receptive endometrium $(77,78)$. However, within days of conception, inflammation must be contained and controlled in order for decidualization and implantation to progress (72). The capacity to resolve decidual inflammation has evolved as a key feature underpinning placentation in viviparous mammals (79), and disturbance to the dynamic balance between pro- and antiinflammatory mediators is a hallmark of impaired implantation $(21,80)$. Through their potent antiinflammatory actions, Tregs appear to be critical for controlling inflammation in early pregnancy and establishing a receptive decidual environment (refs. 18, 81, and Figure 1). 


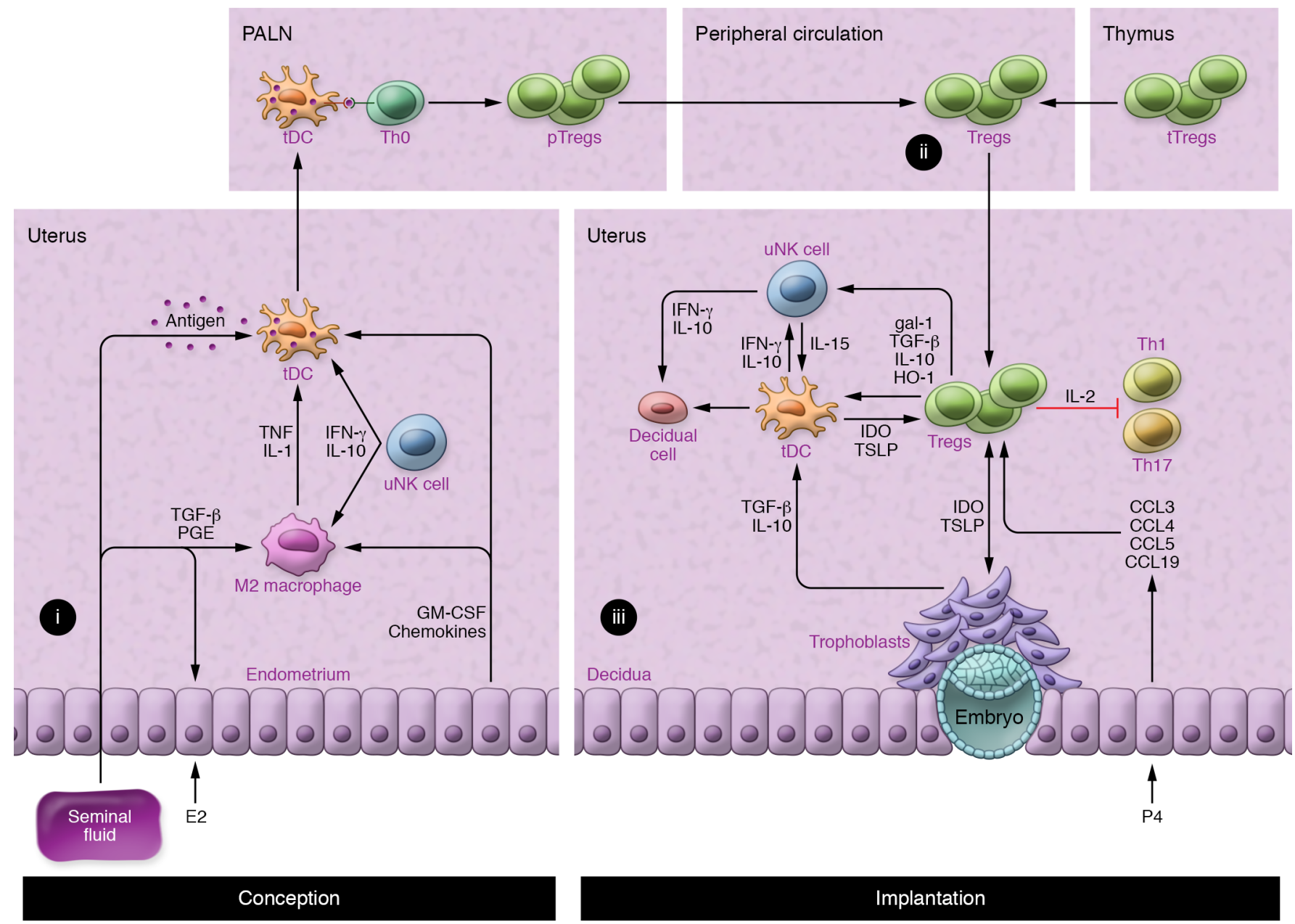

Figure 2. Tregs arise as a result of events initiated at conception, resulting in the recruitment of $p$ Treg and tTreg populations into the uterine decidua at embryo implantation. (i) Estrogen (E2) and seminal fluid induce the recruitment of macrophages and DCs, which acquire M2 and tDC phenotypes in response to TCF- $\beta$ and prostaglandin (PGE) in seminal fluid; granulocyte-macrophage CSF (GM-CSF) and chemokines released by uterine epithelial cells; and IFN- $\gamma$ and IL-10 originating in uNK cells $(38,105,128)$. tDCs take up paternal alloantigens in seminal fluid and traffic to the uterus-draining PALNs (90). (ii) In the PALNs, tDCs present antigen to naive ThO cells, which become activated, proliferate, and differentiate into pTregs before release into the peripheral blood $(39,84,90,137)$. (iii) An expanded pool of peripheral blood pTregs and tTregs $(41,83,139)$ is recruited and retained in the uterus prior to and during embryo implantation in response to epithelial cell-derived CCL3, CCL4, CCL5, and CCL19 (85, 137). Here, Tregs inhibit the activation and function of Th1 and Th17 cells by sequestering IL-2 and other suppressive mechanisms $(53,88,99,100)$ and control inflammation by the release of TCF- $\beta$, IL-10, and HO-1 to interact with DCs and uNKs $(53,88,99,104,105)$. This in turn impairs Th1 survival, promotes further Treg generation $(39,102,103,105)$, and potentially influences decidual transformation and receptivity to embryo implantation (108-110). Treg phenotype and stability are reinforced by IDO and TSLP from tDCs and trophoblasts (111). gal-1, galectin-1; P4, progesterone.

\section{Tregs as essential mediators of pregnancy tolerance}

Experiments in mice provide compelling evidence that Tregs are essential for the antiinflammatory transition accompanying implantation and placental development. Initially, this was shown by transferring $\mathrm{T}$ cells depleted of $\mathrm{CD} 4^{+} \mathrm{CD} 25^{+}$Tregs into pregnant $\mathrm{T}$ celldeficient mice (39). In the absence of Tregs, allogeneic fetuses were uniformly rejected, but Tregs were not essential when fetuses shared maternal MHC (39). Likewise, depletion of $\mathrm{CD} 25^{+} \mathrm{T}$ cells using the PC21 mAb on the day of mating caused a dramatic increase in activated $\mathrm{CD}^{+}$and $\mathrm{CD} 4^{+} \mathrm{T}$ cells in para-aortic lymph nodes (PALNs) draining the uterus, and few fetuses survived in allogeneic pregnancies (82).

Treg dynamics in mice mirror those in human pregnancy, providing a useful model for key regulatory features $(83,84)$. Treg increases at implantation are consistently greater with allogeneic fetuses, indicating fetal antigen-driven expansion, and are accompanied by specific suppression of anti-paternal alloantigen responses $(83,85)$. Male-specific minor antigens such as $\mathrm{H}-\mathrm{Y}$ contribute to driving the Treg response, with male fetuses being more vulnerable to Treg depletion (86).

Studies in which Tregs are depleted at various time points show that the pre- and peri-implantation phase is the most vulnerable. Anti-CD25 Ab administered shortly after mating causes complete implantation failure $(62,87)$. Depletion of $\mathrm{FOXP3}^{+}$cells from Foxp3Dtr mice during early placentation increases later fetal resorption $(41,63)$, but mid-gestation depletion increases fetal death only moderately (40), unless mice receive a second-hit inflammatory challenge $(64,88,89)$. Mice deficient in T cells due to Rag1-null mutation 
A Healthy placentation

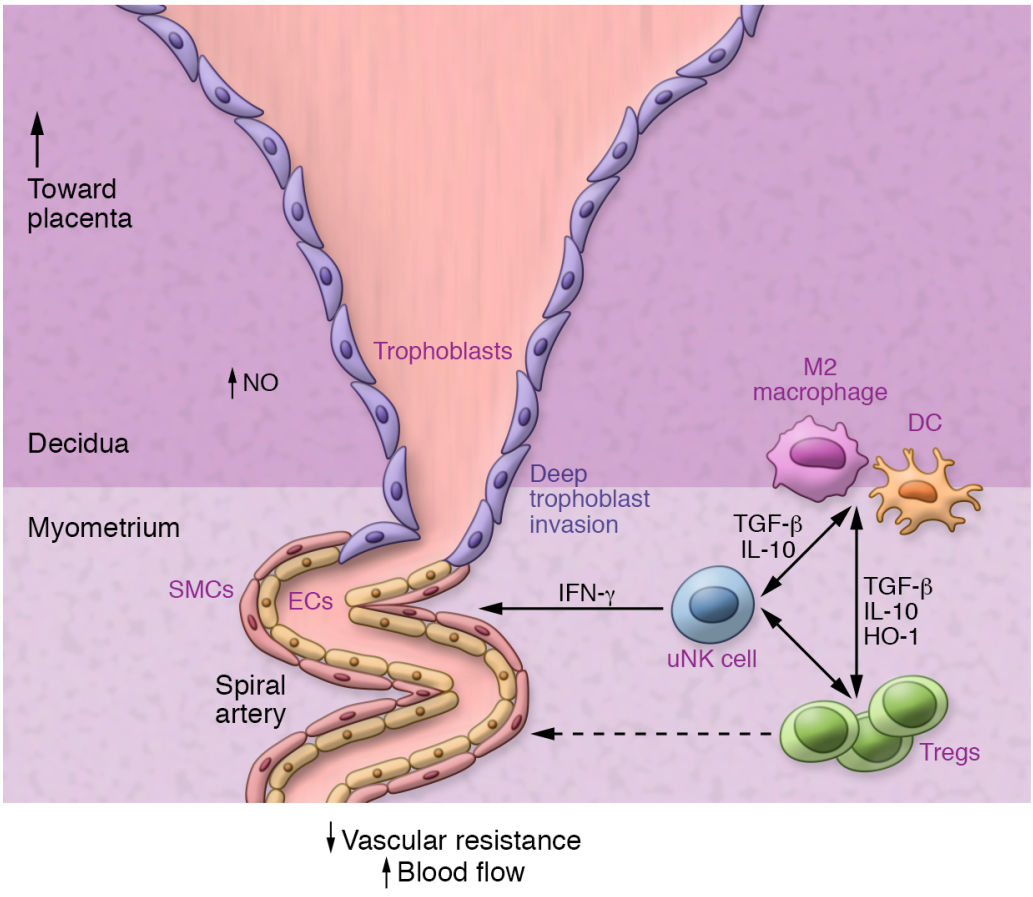

B Shallow placentation

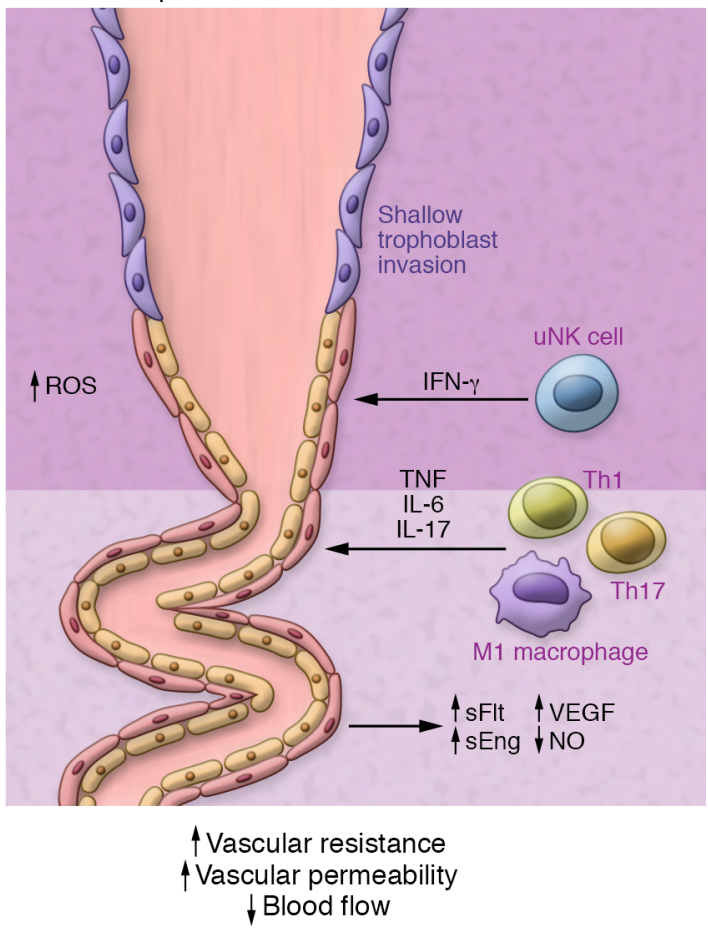

Figure 3. Decidual Tregs facilitate maternal blood vessel adaptation and the transformation of spiral arteries underpinning placental development. (A) Decidual uNK cells release IFN- $\gamma$ to regulate decidual vascular remodeling associated with extravillous trophoblast invasion as well as displacement of endothelial cells and smooth muscle cells (SMCs) (107). Tregs release TCF- $\beta$, IL-10, and HO-1 to suppress inflammatory activation and modulate decidual uNK, macrophage, and DC phenotypes $(53,88,99,104,105)$. The result is reduced vascular resistance and increased blood flow to the developing placenta. (B) When Tregs are deficient, decidual vascular remodeling is impaired $(41,63,116)$, particularly when uNK cells are also dysregulated (115). The effects of Treg cell deficiency may be mediated by elevated decidual Th1 and Th17 cells and/or M1 macrophages $(41,97,99)$. The result is an elevated synthesis of the proinflammatory cytokines TNF, IL-6, and IL-17 that elicit elevated vascular resistance and permeability, causing inflammatory injury accompanied by elevated soluble Flt (sFlt), soluble endoglin (sEng), VEGF, and NO, which in turn impair placental development, resulting in fetal growth restriction $(63,119,120)$. Treg deficiency is thus implicated in contributing to "shallow placentation," the upstream cause of preeclampsia and other gestational disorders in women (27, 70, 176). ET-1, endothelin-1.

are susceptible to inflammation-induced fetal loss, which is mitigated by $\mathrm{CD} 4^{+} \mathrm{T}$ cells that differentiate into Tregs after transfer (64). Tregs also protect against fetal loss elicited by activated invariant NK T cells (iNKT cells) (88) or after IL-10 depletion from NOD mice (89). mAb-mediated depletion of $\mathrm{CD}^{2} 5^{+}$cells in mid-gestation has a less severe impact, but this may be because Teffs as well as Tregs express CD25 and are removed by PC61 mAb treatment $(62,90)$.

Mouse models with a high rate of spontaneous fetal loss reinforce the critical importance of Tregs for implantation. CBA/J females mated with DBA/2J males have fewer Tregs and elevated decidual Th1 cell numbers, attributable to DBA/2J expression of the superantigen MIs $(87,91)$. Adoptive transfer of Tregs from $\mathrm{CBA} / \mathrm{J}$ females mated with BALB/c males elevates decidual Tregs to restore fetal viability (87), but only if Tregs are transferred before embryo implantation (87). These findings confirm that Tregs have essential roles in the uterus, particularly in the peri-implantation period, consistent with managing the antiinflammatory transition required for embryo receptivity (Figure 1).

\section{Mechanisms by which Tregs mediate implantation success}

Mouse studies indicate at least three mechanisms by which Tregs facilitate implantation and placental development (Figure 2). Selective depletion of Tregs, or induction of overwhelming Teff responses, reveals a key function of Tregs in preventing destructive Teff responses to fetal alloantigens $(41,92-94)$. Paternal antigen-reactive $\mathrm{CD} 8^{+}$Teffs arise in uterus-draining lymph nodes in early pregnancy but normally don't exhibit cytotoxicity in mice (95) or women (5). However, excessive IFN- $\gamma$ and IL-2 at priming can promote the generation of cytotoxic $\mathrm{CD} 8^{+} \mathrm{T}$ cells that later drive fetal loss (96), consistent with evidence of CD8 ${ }^{+}$ $\mathrm{T}$ cell-associated trophoblast damage in early-onset preeclampsia (59). Unrestrained Teffs adversely affect placental development in a fetal antigen-independent manner, presumably through inflammatory cytokine release (96), as well as through antigen-dependent trophoblast cytotoxicity $(97,98)$. Decidual Tregs secrete IL-10 and TGF- $\beta$ and express CD25, CTLA4, and PD-L1 $(53,88,99,100)$, all of which are hallmark mediators of Treg suppression that probably contribute to Teff constraint in early pregnancy $(88,101)$.

Second, Tregs regulate other leukocytes and nonhemopoietic cell lineages to influence decidual support of implantation (Figure 2 and ref. 42). Notably, Tregs promote antiinflammatory and tolerogenic phenotypes in alternatively activated (M2) macrophages and tolerogenic DCs (tDCs) through TGF- $\beta$, IL-10, and CTLA4-mediated mechanisms. Indoleamine 2,3-dioxygenase (IDO) produced by tDCs impairs Th1 cell survival $(102,103)$. Additionally, Tregs release heme oxygenase-1 (HO-1), which 
targets uterine DCs and maintains their immature state (104). In turn, these M2 and tDC phenotypes promote further Treg generation $(104,105)$.

In mice, DCs are key regulators of decidual transformation (73, 76), and through regulation of the uterine DC phenotype (104), Tregs may influence the extent and quality of the decidual response (Figure 2). uNK cells also promote decidualization (106) and regulate decidual artery remodeling (107). Tregs may be important regulators of the uNK phenotype and function at implantation (108), since Tregs control IL-15 release from DCs (109) and suppress uNK cytolytic activity (110). Invading trophoblasts engage with Tregs in a reciprocal interaction that modulates the secretory phenotype of both lineages (111). These coordinated interactions allow Tregs to constrain and limit the inflammatory damage and oxidative stress associated with trophoblast invasion (112).

Third, Tregs are emerging as important regulators of the maternal vascular changes that are essential for normal placental development and adequate placental access to maternal blood. Recent studies have shown that Tregs are critical for modulating cardiovascular function and vascular homeostasis (45). How this relates to the vascular changes required for pregnancy is detailed below.

\section{Tregs and maternal vascular adaptation for placental development}

uNK cells regulate decidual blood vessel remodeling to enable vessel dilatation, trophoblast invasion, and secure placental access to maternal blood (ref. 107 and Figure 3). Mouse models show that $\mathrm{T}$ cells can interact with uNK cells to influence the maternal hemodynamic response to pregnancy $(113,114)$, and adverse effects of uNK deficiency on decidual vessel remodeling are exacerbated when $\mathrm{T}$ cells are also deficient (115).

Treg-deficient mice show consistent impairment in uterine spiral arterial modification, reduced placental blood flow, and fetal growth restriction (Figure 3 and refs. 41, 63, 116). Acute depletion of $\mathrm{FOXP}^{+}$Tregs in early pregnancy causes later uterine artery dysfunction associated with increased production of the vasoconstrictor endothelin-1 (ET-1) (63). A particular function for pTregs is indicated by CNS1-null mice, in which deficiency for the Foxp3 enhancer impairs remodeling of uterine spiral arteries and placental development (41). Poor trophoblast invasion and failure to transform spiral arteries is also seen in mice after depletion of proangiogenic, neutrophil-induced Tregs (116).

Hypertensive mouse models indicate that Tregs limit inflammatory injury and oxidative stress to reduce blood pressure and protect against hypertensive damage $(117,118)$. Tregs also protect against hypertension in pregnancy $(63,119)$, with depletion of FOXP3 ${ }^{+}$ Tregs during early pregnancy perturbing the regulation of arterial blood pressure in mid-gestation (63). Rat models of preeclampsia show that Tregs suppress inflammation to reduce blood pressure and progression to preeclampsia-like symptoms. In the reduced uterine perfusion pressure (RUPP) model, reduced uterine artery blood flow results in placental ischemia and oxidative stress and hypertension. This is accompanied by reduced decidual and placental Tregs, elevated CD4 ${ }^{+} \mathrm{T}$ cells and Th17 cells, and increased circulating vasoactive and inflammatory factors TNF, IL-6, and IL-17, resulting in fetal growth restriction (refs. 119, 120 and Figure 3).
The preeclampsia symptoms are $\mathrm{T}$ cell dependent: they cannot be induced in T cell-deficient athymic rats, but can be induced by transfer of Th17 cells (120), and are mitigated by Tregs transferred from pregnant controls (119). Treatments that boost endogenous Tregs, including IL-10 (121) or low-dose CD28 superagonist (119), also reduce hypertension and fetal growth restriction in the RUPP model. In a rat model of preeclampsia, induction of Tregs using a CD28 superagonist treatment alleviates maternal and fetal disease, most effectively in the preimplantation phase (122).

\section{Treg origins and antigen specificity in early pregnancy}

The two lineages of Tregs required for implantation have different ontogenies: tTregs emerge from the thymus fully competent to suppress responses to self and alloantigens, while pTregs differentiate from conventional naive $\mathrm{CD} 4^{+}$precursors in peripheral lymph nodes or tissues (123) following presentation of cognate antigen by tDCs in the presence of IL- 2 and TGF- $\beta$ (124). Both pTregs and recent thymic emigrant (RTE) tTreg populations require antigen contact to activate full suppressive function and memory (125).

Expansion of $\mathrm{CD}^{+}{ }^{+} \mathrm{Helios}^{+} \mathrm{FOXP}^{+}$pTregs predominantly accounts for the Treg expansion in blood and decidua in early human pregnancy (36). This is consistent with nonredundant functions for pTregs shown in CNS1-null mice, wherein elevated fetal loss is attributable to pTreg deficiency (41). Helios ${ }^{+}$tTregs, as opposed to pTregs, may be preferentially recruited into first trimester decidua (56). Among peripheral blood tTregs, the $\mathrm{CD} 45 \mathrm{RA}^{+} \mathrm{CD} 31^{+} \mathrm{RTE}$ population expands in the first trimester and differentiates into CD45RA-CD31- memory Tregs (57).

By using tetramer-based enrichment, selective stimulation and expansion of endogenous Tregs with fetal alloantigen specificity can be demonstrated initially in the PALNs and then decidua in mice (40), explaining why fetal-maternal MHC disparity is an important determinant of Treg numbers (126). Antigen-experienced Tregs retain protective memory for fetal MHC antigen and rapidly reaccumulate during second pregnancies (40). Although antigen is required for Treg generation, the antigen independence of the effector functions of Tregs confers bystander suppression and infectious tolerance that protect a wider array of fetal and placental antigens than the antigens against which the Tregs were initially primed (127).

Contact with conceptus alloantigens must occur under conditions that favor stable Treg (not Teff) development. pTregs require the support of tDCs to differentiate from naive ThO cells. A tolerogenic phenotype is imposed on uterine tDCs by TGF- $\beta$, granulocyte-macrophage-CSF (GM-CSF), IL-10, galectin-1 (gal1 ), and prostaglandin E (refs. 38, 100, 128, and Figure 2). Tregderived IL-10, TGF- $\beta$, and HO- 1 induce tDC and M2 macrophages to express IDO and sustain pTreg generation (102-104). Decidual Tregs also express CTLA4 $(53,105)$, which downregulates the DC costimulatory molecules CD80 and CD86 needed for Teff activation (43). uNK cells contribute to the reinforcement of protolerogenic M2 through IFN- $\gamma$-mediated promotion of IDO expression in decidual M2 macrophages (105) and IL-10-mediated stabilization of tDCs (76). A PD-1-PD-L1 interaction is essential for Treg-mediated protection of alloantigenic fetuses, as shown by fetal death after PD-L1 blockade (129) or in PD-L1-null mutant 
mice, which can be reversed by WT Tregs (130). Trophoblasts reinforce the tDC phenotype and drive local Treg differentiation by inducing DC production of the cytokine thymic stromal lymphopoietin (TSLP) (111).

The significance of antigen exposure for Treg effector function at implantation is evidenced by studies in abortion-prone mice. Tregs are only effective in rescuing fetal loss when transferred from donors carrying MHC-matched fetuses, whereas antigen-inexperienced donor Tregs from nonpregnant mice are ineffective (87). Consistent with a role for fetal alloantigens in facilitating $\mathrm{uNK}$ and Treg responses, studies in congenic mice show that fetal-maternal MHC mismatch promotes decidual vascular adaptations and facilitates fetal growth (9). Nevertheless, endogenous antigens such as hyaluronidase or microbial antigens might also influence the activation and expansion of Tregs in early pregnancy (131).

The majority of $\mathrm{T}$ cells in the human decidua have a memory phenotype (CD45RA- or CD45RO $)(51,132)$. HLA-C is the only polymorphic HLA expressed in human trophoblasts, and fetal-maternal HLA-C mismatch is associated with elevated decidual Tregs (4) and maternal protection from preeclampsia (68). Many decidual Tregs show fetal HLA-C antigen specificity $(54,133)$, but specificity to reproductive and other antigens has not been evaluated.

\section{Seminal fluid priming of Tregs}

In mice, appropriate conditions for $\mathrm{T}$ cell antigen priming occur in two waves during the reproductive process. A first exposure to paternal alloantigens that will later be expressed by the conceptus occurs following contact with seminal fluid at coitus, which primes the activation of antigen-specific Tregs (84). Once placental morphogenesis is complete in mid-gestation and maternal blood contacts the syncytiotrophoblast surface, fetal antigens in the form of placental exosomes are released into the maternal blood, providing a second surge of antigen exposure (134).

The two stages of $\mathrm{T}$ cell activation can be tracked in mice expressing transgenic $\mathrm{T}$ cell receptors (TCRs) that are reactive with surrogate paternal antigens. Mating with male mice engineered to constitutively express OVA in semen elicit a pulse in the proliferation of OVA-reactive $\mathrm{CD}^{+}$and $\mathrm{CD} 8^{+} \mathrm{T}$ cells within the PALNs, followed by a progressive gain in the postimplantation phase once $\mathrm{OVA}^{+}$placental cells contact maternal blood (90). Release of placental microparticles containing OVA sustains a progressively systemic $\mathrm{T}$ cell response until the postpartum phase (90). A similar pattern of $\mathrm{T}$ cell responsiveness is seen in T cell-transgenic models tracking female responses to paternally derived $\mathrm{H}-\mathrm{Y}$ antigen (135).

Seminal fluid contains high levels of TGF- $\beta$ as well as TLR4 ligands, which provoke an inflammation-like response in the female reproductive tract (136), eliciting DCs and macrophages that take up male antigens, traffic to the PALNs, and present antigen to naive T cells (ref. 90 and Figure 2A). This provokes a wave of $\mathrm{T}$ cell activation corresponding with a 2-fold expansion in Tregs detected within days of conception in the PALNs and then the spleen and peripheral blood (refs. 39, 84, 137, and Figure 2B). Circulating Tregs then accumulate in the uterus (39) in response to CCL3, CCL4, CCL5, and CCL19 secreted by epithelial cells $(85,137)$ and may undergo further rounds of proliferation (39) to induce a state of hypo-responsiveness to paternal alloantigens in time for embryo implantation (refs. 84, 135, and Figure 2C).
Mouse studies imply that seminal fluid priming is a key step for expansion of the pTreg population in early pregnancy (41). Consistent with this, pregnancies sired in the absence of seminal fluid contact have poor outcomes (138). The size and suppressive competence of the pTreg pool are determined by the strength of the antigenic challenge and the cytokine context in which antigen contact occurs, parameters determined by seminal fluid composition as well as female tract factors. The plasma fraction of seminal fluid is instrumental in Treg activation, as surgical excision of the seminal vesicle glands ablates the maternal response $(135,137)$ and abrogates the paternal alloantigen hyporesponsiveness seen after mating with intact males (84).

A population of tTregs also expands systemically prior to conception and embryo implantation $(83,139)$. These cells accumulate in the uterus and PALNs during the estrous stage of the reproductive cycle in mice in response to increases in estradiol (E2) at ovulation (139). The antigen specificity of tTregs and whether they can be further stimulated by tDC presentation of seminal fluid or trophoblast antigens is not clear.

In women, vaginal intercourse elicits an immune response to seminal fluid, with elevated cytokine expression, immune cell recruitment, and $\mathrm{T}$ cell activation in the cervix $(140,141)$. Human seminal fluid contains soluble HLA antigens and high levels of TGF- $\beta$ among an array of immune regulatory cytokines (141). Analysis of peripheral blood $\mathrm{T}$ cells provides evidence that prior seminal fluid contact contributes to the priming of paternal antigen-specific Tregs (54) to build on the follicular-phase Treg pool expansion (58). Although it is yet to be proven that seminal fluid induces pTregs in vivo, seminal fluid has been demonstrated to skew DCs to a tDC phenotype and induce Tregs in vitro (141-143). A priming effect of seminal fluid explains the benefit of seminal fluid contact for implantation success in IVF treatment cycles (144) and the protective effect in preeclampsia of sexual cohabitation with the conceiving partner $(145,146)$, particularly when maternal-fetal HLA sharing is greater (68).

\section{T cell imbalance in unexplained infertility, miscarriage, and preeclampsia}

In women with recurrent miscarriage, the luteal-phase endometrium exhibits elevated expression of the inflammatory mediators IL-1B, TNF, and IFN- $\gamma$ and reduced IL-4, IL-6, IL-10, IL-6 family cytokine LIF, and VEGF $(147,148)$, and this is accompanied by altered uNK and T cells (72,149-151) as well as evidence of uterine vascular dysfunction and reduced expression of key angiogenic regulators (152). Together, these observations point to dysfunctional receptivity to implantation stemming from failure to transition to an antiinflammatory and proangiogenic immune environment. This dysfunction is associated with reduced numbers of Tregs in decidua $(20,153-155)$ and peripheral blood $(58,155,156)$ compared with numbers in fertile women. Conversely, IL-17-producing $\mathrm{T}$ cells in peripheral blood and decidua are increased (21, 155), implicating a systemic immune imbalance. Reduced Tregs may precede miscarriage onset, with low circulating Treg numbers in early pregnancy predicting a risk of loss in women with a miscarriage history (157). Tregs from women with recurrent miscarriage exhibit reduced suppressive function (58), with fewer CD45RA ${ }^{-}$cells among the CD45RA-FOXP3 ${ }^{\text {hi }}$ effector pool (56) 
and reduced expression of CTLA4 (153) and Ubc13, an enzyme important for Treg stability $(158,159)$. Conversely decidual Th17 cell numbers are elevated (155), and elevated susceptibility to IL-6 trans-signaling, which can confer abnormal suppressive function and disposition to Th17 conversion, may contribute to this (160).

In primary unexplained infertility, IL-1A, IFN- $\gamma$, and CCL11 are elevated in uterine fluid (161), and increased IL-12, IL-15, and IL-18 levels are linked with elevated UNK numbers in the decidua (80). Reduced endometrial expression of FOXP3 indicates fewer Tregs (19) potentially due to a systemic defect, as IVF success correlates with circulating levels of $\mathrm{CD}^{+} \mathrm{CD} 25^{+} \mathrm{FOXP} 3^{+}$cells $(162$, 163). Primate studies suggest that systemic and endometrial Treg deficiency is exacerbated by endometriosis, a common condition in infertile women (164). The association between reduced fertility and fewer Tregs in asthma (165), allergy (166), and autoimmune disease (167) supports the view of Treg dysfunction as an underlying cause (168).

In preeclampsia, Tregs in the maternal peripheral blood and decidual tissue are reduced $(23,36,59)$, and suppressive function is impaired $(169,170)$, with an accompanying rise in proinflammatory Th17 cells (24), CD8 ${ }^{+}$effector cells, and trophoblast apoptosis (59). This is linked with pTreg deficiency (36), most notable in early-onset severe preeclampsia (59), as well as with CD 45RA ${ }^{+} \mathrm{CD} 31^{+}$RTE tTregs being less able to acquire a memory phenotype (171). Dysfunctional DCs with reduced HLA-G and ILT4 expression (36) and/or insufficient expression of PD-L1 (172) may amplify Treg deficiency.

The clinical features of preeclampsia point to immune priming and memory, invoking a causal role for the adaptive immune response. Preeclampsia is more common in first pregnancies, especially when sexual contact with the conceiving partner has been limited because of a short duration of sexual cohabitation or barrier contraceptive use - and protection afforded by prior pregnancies is lost with a change of partner $(65,145,173)$. Use of donor oocytes in assisted reproduction, where there is no prior contact with the donor's alloantigens, leads to a striking 4.3-fold increase in preeclampsia compared with natural conception (174). With donor sperm, the risk is also increased, but, remarkably, this is mitigated by multiple exposures to the same donor's semen (175).

\section{Inadequate Treg priming and "shallow" placentation}

Considering the extant evidence, it is reasonable to infer that insufficient Tregs in the periconception phase is a key upstream driver of the altered decidual environment and failure to achieve appropriate inflammatory resolution that precede limited invasion of trophoblasts and maternal vessel remodeling, in turn causing "shallow" placentation and ultimately preeclampsia and/or fetal growth impairment in later gestation (refs. 27, 70, 176, and Figure 3). This view fits the emerging paradigm invoking early pregnancy as the origin not just of miscarriage, but also of disorders of placentation linked with early-onset, severe preeclampsia, and as a contributing factor to fetal growth restriction, late spontaneous abortion, and preterm labor $(27,176,177)$. Direct evidence for this comes from transcriptional analysis of chorionic villous samples, showing evidence of immune changes originating at implantation in women who later developed preeclampsia (178).
This raises the question of why some women have insufficient Treg numbers and function. Because newly generated pTregs are more vulnerable to phenotype switching and lineage instability (47), a secure Treg fate will depend on the conception environment. Treg priming may be dysregulated as a result of seminal fluid composition or responsiveness $(112,141)$. For example, when $\mathrm{CD} 4^{+}$cells from patients with recurrent miscarriage are cultured with DCs and the partner's seminal fluid antigens, CD4 $4^{+} \mathrm{IL}-17$ and $\mathrm{CD} 4^{+} \mathrm{IFN}-\gamma^{+}$cells proliferate excessively, and fewer $\mathrm{CD} 4^{+} \mathrm{CD} 25^{+} \mathrm{FOXP}^{+}$Tregs are generated compared with fertile controls (158). The composition of seminal fluid immune-regulatory agents, particularly protolerogenic TGF- $\beta$, varies among and within men over time (179). The antitolerogenic cytokine IFN- $\gamma$, which drives the generation of Th1 immunity, fluctuates substantially in seminal fluid and can be elevated in response to infection (180). IFN- $\gamma$ is elevated in the seminal fluid of male partners of women with recurrent miscarriage $(181,182)$. IFN- $\gamma$ can interfere with the synthesis of GM-CSF required to drive T cell activation at conception $(128,183)$, skew Th0 differentiation toward Th17 cells $(46,184)$, and cause Tregs to transdifferentiate (185).

Bioavailability of cytokines, hormones, and microRNAs and the reproductive tract microbiome in the conception environment all potentially influence the Treg response (186-188). IL-10 deficiency elicits an unstable Treg response at implantation, with more rapid phenotype conversion and a reduced capacity to withstand an inflammatory challenge in later gestation $(101,189)$. Neutrophils also contribute, with neutrophil-depleted mice displaying insufficiency of proangiogenic, neutrophil-induced Tregs (116). Progesterone bioavailability impacts the Treg phenotype and secure fate commitment $(190,191)$, in part by inducing gal-1 to reinforce the tDC phenotype (100). Progesterone is commonly administered as luteal-phase support in IVF cycles (192), but whether this elevates Tregs at implantation remains to be determined.

Within hyperinflammatory environments, pTregs exhibit phenotypic plasticity and lineage instability, with a capacity to shift the phenotype and express cytokines that are characteristic of Teff lineages $(47,185)$. Tregs that undergo transdifferentiation into effector Th1 or Th17 cells, known as exTregs, drive pathology in inflammatory conditions and autoimmune disorders $(193,194)$. Epigenetic regulation of FOXP3 expression is a key determinant of whether T cells can maintain a suppressive phenotype $(195,196)$.

There is emerging evidence for Treg phenotype instability in reproductive disorders. Defects in stability would explain the observations of reduced Treg-suppressive competence (60) and evidence of elevated Th1 and Th17 cells in preeclampsia $(24,99)$. An intrinsic deficiency in peripheral blood Tregs in recurrent miscarriage is indicated by diminished IL- 2 and TGF- $\beta$ secretion as well as reduced IL-2/STAT5 signaling (197), while decidual Tregs have elevated IFN- $\gamma$ expression (198). Exploratory studies implicate gene polymorphisms in the promoter region of FOXP3 in preeclampsia $(199,200)$. Tregs that express insufficient FOXP3 may be phenotypically plastic and express inflammatory cytokines, and exTregs could directly contribute to the pathology.

\section{Conclusions and therapeutic prospects}

Taken together, clinical studies and animal models support the inference that decidual Tregs are rate limiting for resolving inflammation at embryo implantation and establishing a decidual 
environment conducive to implantation receptivity and robust placental formation. It seems likely that in a substantial proportion of cases of infertility, recurrent miscarriage, and preeclampsia, Tregs are central and causal in disease development $(21,80)$. Immune imbalance or maladaptation causing incompetent phenotypes or insufficient Tregs provides a point of intersection channeling environmental, metabolic, and genetic factors (187) that likely interact with clinical factors such as prior pregnancy and male partner histocompatibility, which are identified as important in the prepregnancy antecedents of adverse pregnancy outcomes (22).

The biological properties of Tregs, particularly their responsiveness to environmental context and capacity to undergo phenotype switching $(47,187)$, may confer a maternal ability to distinguish and differentially invest in reproductive opportunities. The capacity of Tregs to transdifferentiate into Teffs in the event of infection, excessive inflammation, or disrupted fetal development (129) confers the capacity to terminate pregnancy and ensure maternal survival. The plasticity of Tregs may thereby provide an evolutionary benefit by contributing to maternal "quality control" that ensures optimal reproductive investment and maximizes offspring fitness (48). Vulnerability to reproductive disorders due to Treg instability $(56,57,170)$ may be the biological trade-off (48).

The recognition that Tregs contribute to and may be causal in disorders of pregnancy raise the prospect of modulating the immune response to suppress the progression of symptoms and/ or prevent their development. Interventions to boost Treg numbers and/or functional competence are in development and show promise for autoimmunity and tissue transplantation (194) and have been explored for cardiovascular disease as well (45). Given the rapid advances in Treg therapeutics, coupled with informative diagnostics based on flow cytometric analysis of peripheral blood, there is a strong prospect of targeting Tregs to tackle immune- based disorders in reproductive and obstetric medicine. Questions to first resolve include the antigen specificity of decidual Tregs, the key female and male partner determinants of optimal Treg generation and phenotype commitment, and the relevance of different Treg subsets including CD $8^{+}$Tregs.

Treg therapies relevant to pregnancy disorders could take one of three approaches: (a) advice on sexual activity, contraception, and lifestyle modifications to promote endogenous Treg generation; (b) in vivo interventions to increase Treg numbers and/or function in an antigen-nonspecific, tissue-targeted, or systemic manner; or (c) cell therapy methods that could include ex vivo generation and/or expansion of Treg numbers in vitro. Candidate biological agents to boost Treg numbers and stability using PF-L1 Fc (172) or CD28 superligand (122) already show a promising proof of concept in mouse models of preeclampsia. It will be important to focus on interventions and matching diagnostics that can be applied sufficiently early in pregnancy to have a reasonable chance of diverting the course of disease development. It is critical that any experimental evaluation of these approaches in a human reproductive setting take a highly cautious approach and be based on robust clinical trial design principles, as the risk-to-benefit ratio in reproductive and obstetric conditions is different than that for life-threatening immune diseases.

\section{Acknowledgments}

SAR has received funding from the National Health and Medical Research Council of Australia (NHMRC) (APP1099461). ASC has received funding from the NHMRC (APP1092191).

Address correspondence to: Sarah A. Robertson, Robinson Research Institute, Adelaide Medical School, University of Adelaide, North Tce, Adelaide 5005, South Australia, Australia. Phone: 618.8313.4094; Email: sarah.robertson@adelaide.edu.au.
1. Schatz F, Guzeloglu-Kayisli O, Arlier S, Kayisli UA, Lockwood CJ. The role of decidual cells in uterine hemostasis, menstruation, inflammation, adverse pregnancy outcomes and abnormal uterine bleeding. Hum Reprod Update. 2016;22(4):497-515.

2. Medawar PB. Some immunological and endocrinological problems raised by the evolution of viviparity in vertebrates. Symp Soc Exp Biol. 1953;7:320-338.

3. Tafuri A, Alferink J, Möller P, Hämmerling GJ, Arnold B. T cell awareness of paternal alloantigens during pregnancy. Science. 1995;270(5236):630-633.

4. Tilburgs T, et al. Fetal-maternal HLA-C mismatch is associated with decidual $\mathrm{T}$ cell activation and induction of functional $\mathrm{T}$ regulatory cells. J Reprod Immunol. 2009;82(2):148-157.

5. Lissauer D, Piper K, Goodyear O, Kilby MD, Moss PA. Fetal-specific CD8+ cytotoxic T cell responses develop during normal human pregnancy and exhibit broad functional capacity. J Immunol. 2012;189(2):1072-1080.

6. Robertson SA, Petroff MG, Hunt JS. Immunology of pregnancy. In: Plant TM, Zeleznik AJ, eds. Knobil and Neill's Physiology of Reproduction. London, United Kingdom: Academic Press;
2015:1835-1874.

7. Bonney EA. Alternative theories: Pregnancy and immune tolerance. J Reprod Immunol. 2017;123:65-71.

8. Anderson MS, Venanzi ES, Chen Z, Berzins SP, Benoist C, Mathis D. The cellular mechanism of Aire control of $\mathrm{T}$ cell tolerance. Immunity. 2005;23(2):227-239.

9. Madeja Z, et al. Paternal MHC expression on mouse trophoblast affects uterine vascularization and fetal growth. Proc Natl Acad Sci U S A. 2011;108(10):4012-4017.

10. Apps R, Murphy SP, Fernando R, Gardner L, Ahad T, Moffett A. Human leucocyte antigen (HLA) expression of primary trophoblast cells and placental cell lines, determined using single antigen beads to characterize allotype specificities of anti-HLA antibodies. Immunology. 2009;127(1):26-39.

11. Kshirsagar SK, et al. Immunomodulatory molecules are released from the first trimester and term placenta via exosomes. Placenta. 2012;33(12):982-990.

12. Tilburgs T, et al. Human $\mathrm{HLA}_{-} \mathrm{G}^{+}$extravillous trophoblasts: Immune-activating cells that interact with decidual leukocytes. Proc Natl Acad Sci U S A. 2015;112(23):7219-7224.
13. Taglauer ES, Trikhacheva AS, Slusser JG, Petroff MG. Expression and function of PDCD1 at the human maternal-fetal interface. Biol Reprod. 2008;79(3):562-569.

14. Collins MK, Tay CS, Erlebacher A. Dendritic cell entrapment within the pregnant uterus inhibits immune surveillance of the maternal/fetal interface in mice. J Clin Invest. 2009;119(7):2062-2073.

15. Nancy P, Tagliani E, Tay CS, Asp P, Levy DE, Erlebacher A. Chemokine gene silencing in decidual stromal cells limits T cell access to the maternalfetal interface. Science. 2012;336(6086):1317-1321.

16. Trowsdale J, Betz AG. Mother's little helpers: mechanisms of maternal-fetal tolerance. Nat Immunol. 2006;7(3):241-246.

17. Moffett A, Loke C. Immunology of placentation in eutherian mammals. Nat Rev Immunol. 2006;6(8):584-594.

18. Erlebacher A. Immunology of the maternal-fetal interface. Annu Rev Immunol. 2013;31:387-411.

19. Jasper MJ, Tremellen KP, Robertson SA. Primary unexplained infertility is associated with reduced expression of the T-regulatory cell transcription factor Foxp3 in endometrial tissue. Mol Hum Reprod. 2006;12(5):301-308.

20. Yang H, Qiu L, Chen G, Ye Z, Lü C, Lin Q. Proportional change of $\mathrm{CD} 4{ }^{+} \mathrm{CD} 25^{+}$regulatory T cells 
in decidua and peripheral blood in unexplained recurrent spontaneous abortion patients. Fertil Steril. 2008;89(3):656-661.

21. Lee SK, et al. An imbalance in interleukin-17-producing $\mathrm{T}$ and Foxp $3^{+}$regulatory $\mathrm{T}$ cells in women with idiopathic recurrent pregnancy loss. Hum Reprod.2011;26(11):2964-2971.

22. Roberts JM, et al. Global Pregnancy Collaboration Symposium: Prepregnancy and very early pregnancy antecedents of adverse pregnancy outcomes: overview and recommendations. Placenta. 2017;60:103-109.

23. Sasaki Y, et al. Proportion of peripheral blood and decidual $\mathrm{CD} 4(+) \mathrm{CD} 25$ (bright) regulatory $\mathrm{T}$ cells in pre-eclampsia. Clin Exp Immunol. 2007;149(1):139-145.

24. Santner-Nanan B, et al. Systemic increase in the ratio between Foxp $3^{+}$and IL-17-producing $\mathrm{CD} 4^{+} \mathrm{T}$ cells in healthy pregnancy but not in preeclampsia. J Immunol. 2009;183(11):7023-7030.

25. Coughlan C, et al. Recurrent implantation failure: definition and management. Reprod Biomed Online. 2014;28(1):14-38.

26. Ford HB, Schust DJ. Recurrent pregnancy loss: etiology, diagnosis, and therapy. Rev Obstet Gynecol. 2009;2(2):76-83.

27. Redman CW, Sargent IL. Immunology of pre-eclampsia. Am J Reprod Immunol. 2010;63(6):534-543.

28. Bilano VL, Ota E, Ganchimeg T, Mori R, Souza JP. Risk factors of pre-eclampsia/eclampsia and its adverse outcomes in low- and middle-income countries: a WHO secondary analysis. PLoS One. 2014;9(3):e91198.

29. Stevens W, et al. Short-term costs of preeclampsia to the United States health care system. Am J Obstet Gynecol. 2017;217(3):237-248.e16.

30. Beer AE, Billingham RE. Maternal immunological recognition mechanisms during pregnancy. Ciba Found Symp. 1978;(64):293-322.

31. Robertson SA, Mau VJ, Hudson SN, Tremellen KP. Cytokine-leukocyte networks and the establishment of pregnancy. Am J Reprod Immunol. 1997;37(6):438-442.

32. Houser BL, Tilburgs T, Hill J, Nicotra ML, Strominger JL. Two unique human decidual macrophage populations. JImmunol. 2011;186(4):2633-2642.

33. Gardner L, Moffett A. Dendritic cells in the human decidua. Biol Reprod. 2003;69(4):1438-1446.

34. Koopman LA, et al. Human decidual natural killer cells are a unique NK cell subset with immunomodulatory potential. J Exp Med. 2003;198(8):1201-1212.

35. Higuma-Myojo S, et al. Cytokine profile of natural killer cells in early human pregnancy. $\mathrm{Am} J$ Reprod Immunol. 2005;54(1):21-29.

36. Hsu P, et al. Altered decidual DC-SIGN+ antigen-presenting cells and impaired regulatory T-cell induction in preeclampsia. Am J Pathol. 2012;181(6):2149-2160.

37. Lash GE, Pitman H, Morgan HL, Innes BA, Agwu CN, Bulmer JN. Decidual macrophages: key regulators of vascular remodeling in human pregnancy. J Leukoc Biol. 2016;100(2):315-325.

38. Blois SM, et al. Dendritic cells: key to fetal tolerance? Biol Reprod. 2007;77(4):590-598.

39. Aluvihare VR, Kallikourdis M, Betz AG. Regulatory $\mathrm{T}$ cells mediate maternal tolerance to the fetus.
Nat Immunol. 2004;5(3):266-271.

40. Rowe JH, Ertelt JM, Xin L, Way SS. Pregnancy imprints regulatory memory that sustains anergy to fetal antigen. Nature. 2012;490(7418):102-106.

41. Samstein RM, Josefowicz SZ, Arvey A, Treuting PM, Rudensky AY. Extrathymic generation of regulatory $\mathrm{T}$ cells in placental mammals mitigates maternal-fetal conflict. Cell. 2012;150(1):29-38.

42. Guerin LR, Prins JR, Robertson SA. Regulatory $\mathrm{T}$-cells and immune tolerance in pregnancy: a new target for infertility treatment? Hum Reprod Update. 2009;15(5):517-535.

43. Sakaguchi S, Yamaguchi T, Nomura T, Ono M. Regulatory $\mathrm{T}$ cells and immune tolerance. Cell. 2008;133(5):775-787.

44. Rudensky AY. Regulatory T cells and Foxp3. Immunol Rev. 2011;241(1):260-268.

45. Yamashita T, Sasaki N, Kasahara K, Hirata K. Anti-inflammatory and immune-modulatory therapies for preventing atherosclerotic cardiovascular disease. J Cardiol. 2015;66(1):1-8.

46. Bettelli E, et al. Reciprocal developmental pathways for the generation of pathogenic effector TH17 and regulatory T cells. Nature. 2006;441(7090):235-238

47. Hori S. Lineage stability and phenotypic plasticity of Foxp $3^{+}$regulatory T cells. Immunol Rev. 2014;259(1):159-172.

48. Robertson SA. Immune regulation of conception and embryo implantation - all about quality control? J Reprod Immunol. 2010;85(1):51-57.

49. Williams PJ, Searle RF, Robson SC, Innes BA, Bulmer JN. Decidual leucocyte populations in early to late gestation normal human pregnancy. JReprod Immunol. 2009;82(1):24-31.

50. Shao L, Jacobs AR, Johnson VV, Mayer L. Activation of $\mathrm{CD} 8^{+}$regulatory $\mathrm{T}$ cells by human placental trophoblasts. JImmunol. 2005;174(12):7539-7547.

51. Tilburgs T, et al. Human decidual tissue contains differentiated $\mathrm{CD} 8^{+}$effector-memory T cells with unique properties. JImmunol. 2010;185(7):4470-4477.

52. Dimova T, et al. Maternal Foxp3 expressing $\mathrm{CD} 4^{+} \mathrm{CD} 25^{+}$and $\mathrm{CD} 4^{+} \mathrm{CD} 25^{-}$regulatory T-cell populations are enriched in human early normal pregnancy decidua: a phenotypic study of paired decidual and peripheral blood samples. Am J Reprod Immunol. 2011;66(suppl 1):44-56.

53. Mjösberg J, Berg G, Jenmalm MC, Ernerudh J. FOXP $^{+}$regulatory $\mathrm{T}$ cells and $\mathrm{T}$ helper $1, \mathrm{~T}$ helper 2, and Thelper 17 cells in human early pregnancy decidua. Biol Reprod. 2010;82(4):698-705

54. Tilburgs T, et al. Evidence for a selective migration of fetus-specific $\mathrm{CD} 4{ }^{+} \mathrm{CD} 25^{\text {bight }}$ regulatory $\mathrm{T}$ cells from the peripheral blood to the decidua in human pregnancy.JImmunol. 2008;180(8):5737-5745.

55. Nakashima A, Ito M, Yoneda S, Shiozaki A, Hidaka T, Saito S. Circulating and decidual Th17 cell levels in healthy pregnancy. Am J Reprod Immunol. 2010;63(2):104-109.

56. Inada K, Shima T, Ito M, Ushijima A, Saito S. Helios-positive functional regulatory $\mathrm{T}$ cells are decreased in decidua of miscarriage cases with normal fetal chromosomal content. J Reprod Immunol. 2015;107:10-19.

57. Wagner MI, et al. Differentiation of $\mathrm{ICOS}^{+}$and ICOS- recent thymic emigrant regulatory $\mathrm{T}$ cells
(RTE T regs) during normal pregnancy, pre-eclampsia and HELLP syndrome. Clin Exp Iтmunol. 2016;183(1):129-142.

58. Arruvito L, Sanz M, Banham AH, Fainboim L. Expansion of $\mathrm{CD}^{+}{ }^{+} \mathrm{CD} 25^{+}$and $\mathrm{FOXP} 3^{+}$regulatory $\mathrm{T}$ cells during the follicular phase of the menstrual cycle: implications for human reproduction. J Immunol. 2007;178(4):2572-2578.

59. Quinn KH, Lacoursiere DY, Cui L, Bui J, Parast MM. The unique pathophysiology of early-onset severe preeclampsia: role of decidual $\mathrm{T}$ regulatory cells. J Reprod Immunol. 2011;91(1-2):76-82.

60. Steinborn A, et al. Distinct subsets of regulatory $\mathrm{T}$ cells during pregnancy: is the imbalance of these subsets involved in the pathogenesis of preeclampsia? Clin Immunol. 2008;129(3):401-412.

61. Mjösberg J, et al. Systemic reduction of functionally suppressive $\mathrm{CD} 4{ }^{\mathrm{dim}} \mathrm{CD} 25^{\text {high }} \mathrm{Foxp} 3^{+}$Tregs in human second trimester pregnancy is induced by progesterone and 17 $\beta$-estradiol. J Immunol. 2009;183(1):759-769.

62. Shima $\mathrm{T}$, et al. Regulatory $\mathrm{T}$ cells are necessary for implantation and maintenance of early pregnancy but not late pregnancy in allogeneic mice. J Reprod Immunol. 2010;85(2):121-129.

63. Care AS, Bourque SL, Morton JS, Hjartarson EP, Robertson SA, Davidge ST. Reduction in regulatory $\mathrm{T}$ cells in early pregnancy causes uterine artery dysfunction in mice. Hypertension. 2018;72(1):177-187.

64. Bizargity P, Del Rio R, Phillippe M, Teuscher C, Bonney EA. Resistance to lipopolysaccharide-induced preterm delivery mediated by regulatory $\mathrm{T}$ cell function in mice. Biol Reprod. 2009;80(5):874-881.

65. Kho EM, et al. Duration of sexual relationship and its effect on preeclampsia and small for gestational age perinatal outcome. J Reprod Immunol. 2009;82(1):66-73.

66. Johnsen GM, et al. The combination of maternal KIR-B and fetal HLA-C2 is associated with decidua basalis acute atherosis in pregnancies with preeclampsia. J Reprod Immunol. 2018;129:23-29.

67. Meuleman T, Lashley LE, Dekkers OM, van Lith JM, Claas FH, Bloemenkamp KW. HLA associations and HLA sharing in recurrent miscarriage: a systematic review and meta-analysis. Hum Immunol. 2015;76(5):362-373.

68. Triche EW, Harland KK, Field EH, Rubenstein LM, Saftlas AF. Maternal-fetal HLA sharing and preeclampsia: variation in effects by seminal fluid exposure in a case-control study of nulliparous women in Iowa. J Reprod Immunol. 2014;101-102:111-119.

69. Perez-Garcia V, et al. Placentation defects are highly prevalent in embryonic lethal mouse mutants. Nature. 2018;555(7697):463-468.

70. Huppertz B. Placental origins of preeclampsia: challenging the current hypothesis. Hypertension. 2008;51(4):970-975.

71. Evans J, et al. Fertile ground: human endometrial programming and lessons in health and disease. Nat Rev Endocrinol. 2016;12(11):654-667.

72. Kwak-Kim J, Bao S, Lee SK, Kim JW, Gilman-Sachs A. Immunological modes of pregnancy loss: inflammation, immune effectors, and stress. Am J Reprod Immunol. 2014;72(2):129-140. 
73. Plaks V, et al. Uterine DCs are crucial for decidua formation during embryo implantation in mice. JClin Invest. 2008;118(12):3954-3965.

74. Blois SM, et al. Interaction between dendritic cells and natural killer cells during pregnancy in mice. J Mol Med. 2008;86(7):837-852.

75. Croy BA, Wessels J, Linton N, Tayade C. Comparison of immune cell recruitment and function in endometrium during development of epitheliochorial (pig) and hemochorial (mouse and human) placentas. Placenta. 2009;30(suppl A):S26-S31.

76. Tirado-González I, et al. Uterine NK cells are critical in shaping DC immunogenic functions compatible with pregnancy progression. PLoS One. 2012;7(10):e46755.

77. Dekel N, Gnainsky Y, Granot I, Racicot K, Mor G. The role of inflammation for a successful implantation. Am J Reprod Immunol. 2014;72(2):141-147.

78. Gnainsky Y, et al. Local injury of the endometrium induces an inflammatory response that promotes successful implantation. Fertil Steril. 2010;94(6):2030-2036.

79. Griffith OW, Chavan AR, Protopapas S, Maziarz J, Romero R, Wagner GP. Embryo implantation evolved from an ancestral inflammatory attachment reaction. Proc Natl Acad Sci U S A. 2017;114(32):E6566-E6575.

80. Lédée $\mathrm{N}$, et al. The Uterine Immune profile may help women with repeated unexplained embryo implantation failure after in vitro fertilization. Am J Reprod Immunol. 2016;75(3):388-401.

81. Robertson SA, Moldenhauer LM. Immunological determinants of implantation success. Int J Dev Biol. 2014;58(2-4):205-217.

82. Darrasse-Jèze G, Darasse-Jèze G, Klatzmann D, Charlotte F, Salomon BL, Cohen JL. CD $4{ }^{+} \mathrm{CD} 25^{+}$ regulatory/suppressor T cells prevent allogeneic fetus rejection in mice. Immunol Lett. 2006;102(1):106-109.

83. Zhao JX, Zeng YY, Liu Y. Fetal alloantigen is responsible for the expansion of the CD4(+) CD25(+) regulatory $\mathrm{T}$ cell pool during pregnancy. J Reprod Immunol. 2007;75(2):71-81.

84. Robertson SA, Guerin LR, Bromfield JJ, Branson KM, Ahlström AC, Care AS. Seminal fluid drives expansion of the $\mathrm{CD} 4^{+} \mathrm{CD} 25^{+} \mathrm{T}$ regulatory cell pool and induces tolerance to paternal alloantigens in mice. Biol Reprod. 2009;80(5):1036-1045.

85. Kallikourdis M, Andersen KG, Welch KA, Betz AG. Alloantigen-enhanced accumulation of CCR5 + 'effector' regulatory T cells in the gravid uterus. Proc Natl Acad Sci US A. 2007;104(2):594-599.

86. Kahn DA, Baltimore D. Pregnancy induces a fetal antigen-specific maternal $\mathrm{T}$ regulatory cell response that contributes to tolerance. Proc Natl Acad Sci U S A. 2010;107(20):9299-9304.

87. Zenclussen AC, et al. Abnormal T-cell reactivity against paternal antigens in spontaneous abortion: adoptive transfer of pregnancy-induced $\mathrm{CD} 4{ }^{+} \mathrm{CD} 25^{+} \mathrm{T}$ regulatory cells prevents fetal rejection in a murine abortion model. $\mathrm{Am} \mathrm{J}$ Pathol. 2005;166(3):811-822.

88. Li L, Tu J, Jiang Y, Zhou J, Schust DJ. Regulatory $\mathrm{T}$ cells decrease invariant natural killer $\mathrm{T}$ cellmediated pregnancy loss in mice. Mucosal Immu nol. 2017;10(3):613-623.

89. Lin Y, Liu X, Shan B, Wu J, Sharma S, Sun Y. Pre- vention of CpG-induced pregnancy disruption by adoptive transfer of in vitro-induced regulatory $\mathrm{T}$ cells. PLoS One. 2014;9(4):e94702.

90. Moldenhauer LM, Diener KR, Thring DM, Brown MP, Hayball JD, Robertson SA. Crosspresentation of male seminal fluid antigens elicits $\mathrm{T}$ cell activation to initiate the female immune response to pregnancy. Jimmunol. 2009;182(12):8080-8093.

91. Thuere C, et al. Kinetics of regulatory T cells during murine pregnancy. Am J Reprod Immunol. 2007;58(6):514-523.

92. Zenclussen AC, Fest S, Joachim R, Klapp BF, Arck PC. Introducing a mouse model for pre-eclampsia: adoptive transfer of activated Th1 cells leads to pre-eclampsia-like symptoms exclusively in pregnant mice. Eur J Immunol. 2004;34(2):377-387.

93. Wegorzewska M, et al. Fetal intervention increases maternal $\mathrm{T}$ cell awareness of the foreign conceptus and can lead to immune-mediated fetal demise. J Immunol. 2014;192(4):1938-1945.

94. Xin L, et al. Cutting edge: committed Th1 CD4 ${ }^{+}$ $\mathrm{T}$ cell differentiation blocks pregnancy-induced Foxp3 expression with antigen-specific fetal loss. J Immunol. 2014;192(7):2970-2974.

95. Moldenhauer LM, Hayball JD, Robertson SA. Utilising $\mathrm{T}$ cell receptor transgenic mice to define mechanisms of maternal $\mathrm{T}$ cell tolerance in pregnancy. J Reprod Immunol. 2010;87(1-2):1-13.

96. Moldenhauer LM, Diener KR, Hayball JD, Robertson SA. An immunogenic phenotype in paternal antigen-specific $\mathrm{CD}^{+} \mathrm{T}$ cells at embryo implantation elicits later fetal loss in mice. Immu nol Cell Biol. 2017;95(8):705-715.

97. Chaturvedi V, et al. CXCR3 blockade protects against Listeria monocytogenes infection-induced fetal wastage. J Clin Invest. 2015;125(4):1713-1725.

98. Mellor AL, et al. Prevention of T cell-driven complement activation and inflammation by tryptophan catabolism during pregnancy. Nat Immunol. 2001;2(1):64-68.

99. Zhang Y, Liu Z, Tian M, Hu X, Wang L, Ji J, Liao A. The altered PD-1/PD-L1 pathway delivers the 'one-two punch' effects to promote the Treg/Th17 imbalance in pre-eclampsia. Cell Mol Immunol. 2018;15(7):710-723.

100. Blois SM, et al. A pivotal role for galectin-1 in fetomaternal tolerance. NatMed.2007;13(12):1450-1457.

101.Prins JR, Zhang B, Schjenken JE, Guerin LR, Barry SC, Robertson SA. Unstable Foxp $3^{+}$regulatory $\mathrm{T}$ cells and altered dendritic cells are associated with lipopolysaccharide-induced fetal loss in pregnant interleukin 10-deficient mice. Biol Reprod. 2015;93(4):95.

102. Fallarino F, et al. Modulation of tryptophan catabolism by regulatory T cells. Nat Immunol. 2003;4(12):1206-1212.

103. Munn DH, et al. Prevention of allogeneic fetal rejection by tryptophan catabolism. Science. 1998;281(5380):1191-1193.

104.Schumacher A, et al. Blockage of heme oxygenase- 1 abrogates the protective effect of regulatory $\mathrm{T}$ cells on murine pregnancy and promotes the maturation of dendritic cells. PLoS One. 2012;7(8):e42301.

105. Vacca P, et al. Crosstalk between decidual NK and CD14+ myelomonocytic cells results in induction of Tregs and immunosuppression. Proc Natl Acad Sci U S A. 2010;107(26):11918-11923.

106. Blois SM, Klapp BF, Barrientos G. Decidualization and angiogenesis in early pregnancy: unravelling the functions of DC and NK cells. J Reprod Immunol. 2011;88(2):86-92.

107. Ashkar AA, Di Santo JP, Croy BA. Interferon gamma contributes to initiation of uterine vascular modification, decidual integrity, and uterine natural killer cell maturation during normal murine pregnancy. JExpMed.2000;192(2):259-270.

108.Zhang J, Dunk C, Croy AB, Lye SJ. To serve and to protect: the role of decidual innate immune cells on human pregnancy. Cell Tissue Res. 2016;363(1):249-265.

109. Terme M, Chaput N, Combadiere B, Ma A, Ohteki T, Zitvogel L. Regulatory T cells control dendritic cell/NK cell cross-talk in lymph nodes at the steady state by inhibiting $\mathrm{CD}^{+}$self-reactive T cells. JImmunol. 2008;180(7):4679-4686.

110. Ghiringhelli $\mathrm{F}$, et al. $\mathrm{CD} 4{ }^{+} \mathrm{CD} 25^{+}$regulatory $\mathrm{T}$ cells inhibit natural killer cell functions in a transforming growth factor- $\beta$-dependent manner. JExp Med. 2005;202(8):1075-1085.

111. Du MR, et al. Embryonic trophoblasts induce decidual regulatory $\mathrm{T}$ cell differentiation and maternal-fetal tolerance through thymic stromal lymphopoietin instructing dendritic cells. Jimmunol. 2014;192(4):1502-1511.

112. Saito S, Sakai M, SasakiY, Nakashima A, Shiozaki A. Inadequate tolerance induction may induce preeclampsia. JReprod Immunol. 2007;76(1-2):30-39.

113. Croy BA, et al. Identification of the primary outcomes that result from deficient spiral arterial modification in pregnant mice. Pregnancy Hypertens. 2011;1(1):87-94.

114. Burke SD, Barrette VF, Carter AL, Gravel J, Adams MA, Croy BA. Cardiovascular adaptations of pregnancy in $\mathrm{T}$ and $\mathrm{B}$ cell-deficient mice. Biol Reprod. 2011;85(3):605-614.

115. Kieckbusch J, Gaynor LM, Moffett A, Colucci F. MHC-dependent inhibition of uterine NK cells impedes fetal growth and decidual vascular remodelling. Nat Commun. 2014;5:3359.

116. Nadkarni S, et al. Neutrophils induce proangiogenic $\mathrm{T}$ cells with a regulatory phenotype in pregnancy. Proc Natl Acad Sci U S A. 2016;113(52):E8415-E8424.

117. Matrougui K, et al. Natural regulatory T cells control coronary arteriolar endothelial dysfunction in hypertensive mice. Am J Pathol. 2011;178(1):434-441.

118. Maganto-García E, et al. Foxp3+-inducible regulatory $\mathrm{T}$ cells suppress endothelial activation and leukocyte recruitment. JImmunol. 2011;187(7):3521-3529.

119. Cornelius DC, et al. An increased population of regulatory $\mathrm{T}$ cells improves the pathophysiology of placental ischemia in a rat model of preeclampsia. Am J Physiol Regul Integr Comp Physiol. 2015;309(8):R884-R891.

120. Cornelius DC, et al. Reduced uterine perfusion pressure T-helper 17 cells cause pathophysiology associated with preeclampsia during pregnancy. Am J Physiol Regul Integr Comp Physiol. 2016;311(6):R1192-R1199.

121. Harmon A, et al. IL-10 supplementation increases Tregs and decreases hypertension in the RUPP 
rat model of preeclampsia. Hypertens Pregnancy. 2015;34(3):291-306.

122. Przybyl $\mathrm{L}$, et al. Regulatory $\mathrm{T}$ cells ameliorate intrauterine growth retardation in a transgenic rat model for preeclampsia. Hypertension. 2015;65(6):1298-1306.

123. Josefowicz SZ, Lu LF, Rudensky AY. Regulatory $T$ cells: mechanisms of differentiation and function. Annu Rev Immunol. 2012;30:531-564.

124. Chen $\mathrm{W}$, et al. Conversion of peripheral $\mathrm{CD}^{+} \mathrm{CD} 25^{-}$naive $\mathrm{T}$ cells to $\mathrm{CD} 4^{+} \mathrm{CD} 25^{+}$regulatory T cells by TGF-beta induction of transcription factor Foxp3. J Exp Med. 2003;198(12):1875-1886.

125. Kohler S, Thiel A. Life after the thymus: CD31+ and CD31-human naive $\mathrm{CD} 4^{+} \mathrm{T}$-cell subsets. Blood. 2009;113(4):769-774.

126.Zhao JX, Zeng YY, Liu Y. Fetal alloantigen is responsible for the expansion of the $\mathrm{CD} 4(+)$ $\mathrm{CD} 25(+)$ regulatory $\mathrm{T}$ cell pool during pregnancy. J Reprod Immunol. 2007;75(2):71-81.

127. Tang $\mathrm{Q}$, Bluestone JA. The Foxp $3^{+}$regulatory $\mathrm{T}$ cell: a jack of all trades, master of regulation. Nat Immunol. 2008;9(3):239-244.

128. Moldenhauer LM, Keenihan SN, Hayball JD, Robertson SA. GM-CSF is an essential regulator of $\mathrm{T}$ cell activation competence in uterine dendritic cells during early pregnancy in mice. JImmunol. 2010;185(11):7085-7096.

129. D'Addio F, et al. The link between the PDL1 costimulatory pathway and Th17 in fetomaternal tolerance. J Immunol. 2011;187(9):4530-4541.

130. Habicht A, et al. A link between PDL1 and T regulatory cells in fetomaternal tolerance. JImmunol. 2007;179(8):5211-5219.

131. Chen $\mathrm{T}$, et al. Self-specific memory regulatory $\mathrm{T}$ cells protect embryos at implantation in mice. J Immunol. 2013;191(5):2273-2281.

132. Saito S, et al. A study of CD45RO, CD45RA and CD29 antigen expression on human decidual T cells in an early stage of pregnancy. Immunol Lett. 1994;40(3):193-197.

133. Mjösberg J, Berg G, Ernerudh J, Ekerfelt C. CD4+ $\mathrm{CD} 25+$ regulatory $\mathrm{T}$ cells in human pregnancy: development of a Treg-MLC-ELISPOT suppression assay and indications of paternal specific Tregs. Immunology. 2007;120(4):456-466.

134. Chamley LW, Chen Q, Ding J, Stone PR, Abumaree M. Trophoblast deportation: just a waste disposal system or antigen sharing? J Reprod Immunol. 2011;88(2):99-105.

135. Shima T, et al. Paternal antigen-specific proliferating regulatory $\mathrm{T}$ cells are increased in uterine-draining lymph nodes just before implantation and in pregnant uterus just after implantation by seminal plasma-priming in allogeneic mouse pregnancy. J Reprod Immunol. 2015;108:72-82.

136.Schjenken JE, Glynn DJ, Sharkey DJ, Robertson SA. TLR4 signaling is a major mediator of the female tract response to seminal fluid in mice. Biol Reprod. 2015;93(3):68.

137. Guerin LR, Moldenhauer LM, Prins JR, Bromfield JJ, Hayball JD, Robertson SA. Seminal fluid regulates accumulation of FOXP3+ regulatory $\mathrm{T}$ cells in the preimplantation mouse uterus through expanding the $\mathrm{FOXP}^{+}$cell pool and CCL19-mediated recruitment. Biol Reprod. 2011;85(2):397-408.
138. Bromfield JJ, Schjenken JE, Chin PY, Care AS, Jasper MJ, Robertson SA. Maternal tract factors contribute to paternal seminal fluid impact on metabolic phenotype in offspring. Proc Natl Acad Sci U S A. 2014;111(6):2200-2205.

139. Kallikourdis M, Betz AG. Periodic accumulation of regulatory $\mathrm{T}$ cells in the uterus: preparation for the implantation of a semi-allogeneic fetus? PLoS One. 2007;2(4):e382.

140. Sharkey DJ, Tremellen KP, Jasper MJ, Gemzell-Danielsson K, Robertson SA. Seminal fluid induces leukocyte recruitment and cytokine and chemokine mRNA expression in the human cervix after coitus. JImmunol. 2012;188(5):2445-2454 .

141. Robertson SA, Sharkey DJ. Seminal fluid and fertility in women. Fertil Steril. 2016;106(3):511-519.

142.Balandya E, Wieland-Alter W, Sanders K, Lahey T. Human seminal plasma fosters CD4(+) regulatory T-cell phenotype and transforming growth factor- $\beta 1$ expression. Am J Reprod Immunol. 2012;68(4):322-330.

143. Meuleman T, et al. The immunomodulating effect of seminal plasma on T cells. J Reprod Immunol. 2015;110:109-116.

144.Crawford G, Ray A, Gudi A, Shah A, Homburg $R$. The role of seminal plasma for improved outcomes during in vitro fertilization treatment: review of the literature and meta-analysis. Hum Reprod Update. 2015;21(2):275-284.

145. Dekker G. The partner's role in the etiology of preeclampsia. J Reprod Immunol. 2002;57(1-2):203-215

146.Saftlas AF, Rubenstein L, Prater K, Harland KK, Field E, Triche EW. Cumulative exposure to paternal seminal fluid prior to conception and subsequent risk of preeclampsia. J Reprod Immunol. 2014;101-102:104-110.

147. von Wolff M, Thaler CJ, Strowitzki T, Broome J, Stolz W, Tabibzadeh S. Regulated expression of cytokines in human endometrium throughout the menstrual cycle: dysregulation in habitual abortion. Mol Hum Reprod. 2000;6(7):627-634.

148. Banerjee P, Jana SK, Pasricha P, Ghosh S, Chakravarty B, Chaudhury K. Proinflammatory cytokines induced altered expression of cyclooxygenase-2 gene results in unreceptive endometrium in women with idiopathic recurrent spontaneous miscarriage. Fertil Steril. 2013;99(1):179-187.

149. Michimata T, et al. Decrease of T-helper 2 and T-cytotoxic 2 cells at implantation sites occurs in unexplained recurrent spontaneous abortion with normal chromosomal content. Hum Reprod. 2003;18(7):1523-1528.

150. Lissauer D, Goodyear O, Khanum R, Moss PA, Kilby MD. Profile of maternal CD4 T-cell effector function during normal pregnancy and in women with a history of recurrent miscarriage. Clin Sci. 2014;126(5):347-354.

151. Lédée N, et al. Specific and extensive endometrial deregulation is present before conception in IVF/ICSI repeated implantation failures (IF) or recurrent miscarriages. J Pathol. 2011;225(4):554-564.

152. Banerjee P, et al. Identification of key contributory factors responsible for vascular dysfunction in idiopathic recurrent spontaneous miscarriage. PLoS One. 2013;8(11):e80940.

153. Jin LP, Chen QY, Zhang T, Guo PF, Li DJ. The CD4+CD 25 bright regulatory $T$ cells and CTLA-
4 expression in peripheral and decidual lymphocytes are down-regulated in human miscarriage. Clin Immunol. 2009;133(3):402-410.

154.Inada K, Shima T, Nakashima A, Aoki K, Ito M, Saito S. Characterization of regulatory $\mathrm{T}$ cells in decidua of miscarriage cases with abnormal or normal fetal chromosomal content. J Reprod Immunol. 2013;97(1):104-111.

155. Wang WJ, et al. Increased prevalence of $\mathrm{T}$ helper 17 (Th17) cells in peripheral blood and decidua in unexplained recurrent spontaneous abortion patients. J Reprod Immunol. 2010;84(2):164-170.

156. Sasaki Y, Sakai M, Miyazaki S, Higuma S, Shiozaki A, Saito S. Decidual and peripheral blood $\mathrm{CD} 4^{+} \mathrm{CD} 25^{+}$regulatory $\mathrm{T}$ cells in early pregnancy subjects and spontaneous abortion cases. Mol Hum Reprod. 2004;10(5):347-353.

157. Winger EE, Reed JL. Low circulating CD4(+) CD25(+) Foxp3(+) T regulatory cell levels predict miscarriage risk in newly pregnant women with a history of failure. Am J Reprod Immunol. 2011;66(4):320-328.

158. Liu C, Wang XZ, Sun XB. Assessment of sperm antigen specific $T$ regulatory cells in women with recurrent miscarriage. Early Hum Dev. 2013;89(2):95-100.

159. Chang JH, et al. Ubc13 maintains the suppressive function of regulatory $\mathrm{T}$ cells and prevents their conversion into effector-like T cells. Nat Immunol. 2012;13(5):481-490.

160.Arruvito L, Billordo A, Capucchio M, Prada ME, Fainboim L. IL-6 trans-signaling and the frequency of $\mathrm{CD}^{+} \mathrm{FOXP}^{+}$cells in women with reproductive failure. J Reprod Immunol. 2009;82(2):158-165.

161. Fitzgerald HC, Salamonsen LA, Rombauts LJ, Vollenhoven BJ, Edgell TA. The proliferative phase underpins endometrial development: altered cytokine profiles in uterine lavage fluid of women with idiopathic infertility. Cytokine. 2016;88:12-19.

162.Zhou J, Wang Z, Zhao X, Wang J, Sun H, Hu Y. An increase of Treg cells in the peripheral blood is associated with a better in vitro fertilization treatment outcome. Am J Reprod Immunol. 2012;68(2):100-106.

163. Lu Y, Zhang F, Zhang Y, Zeng B, Hu L, Liao A. Quantitative reduction of peripheral $\mathrm{CD} 4^{+} \mathrm{CD} 25^{+}$ $\mathrm{FOXP}^{+}$regulatory $\mathrm{T}$ cells in reproductive failure after artificial insemination by donor sperm. $A m J$ Reprod Immunol. 2013;69(2):188-193.

164. Braundmeier A, Jackson K, Hastings J, Koehler J, Nowak R, Fazleabas A. Induction of endometriosis alters the peripheral and endometrial regulatory $\mathrm{T}$ cell population in the non-human primate. Hum Reprod. 2012;27(6):1712-1722.

165. Toldi G, et al. Peripheral T(h)1/T(h)2/T(h)17/ regulatory $\mathrm{T}$-cell balance in asthmatic pregnancy. Int Immunol. 2011;23(11):669-677.

166. Wegienka $G$, et al. Within-woman change in regulatory $\mathrm{T}$ cells from pregnancy to the postpartum period. J Reprod Immunol. 2011;88(1):58-65.

167. Varghese S, Crocker I, Bruce IN, Tower C. Systemic lupus erythematosus, regulatory $\mathrm{T}$ cells and pregnancy. Expert Rev Clin Immunol. 2011;7(5):635-648

168. Gleicher N. Maternal autoimmunity and adverse pregnancy outcomes. JAutoimmun. 2014;50:83-86. 
169. Darmochwal-Kolarz D, et al. The predominance of Th17 lymphocytes and decreased number and function of Treg cells in preeclampsia. J Reprod Immunol. 2012;93(2):75-81.

170.Steinborn A, et al. Pregnancy-associated diseases are characterized by the composition of the systemic regulatory $\mathrm{T}$ cell (Treg) pool with distinct subsets of Tregs. Clin Exp Immunol. 2012;167(1):84-98

171. Wagner JM, et al. Analysis of pregnancy-associated major basic protein levels throughout gestation. Placenta.1993;14(6):671-681.

172. Tian M, Zhang Y, Liu Z, Sun G, Mor G, Liao A. The PD-1/PD-L1 inhibitory pathway is altered in pre-eclampsia and regulates $T$ cell responses in pre-eclamptic rats. Sci Rep. 2016;6:27683.

173. Klonoff-Cohen HS, Savitz DA, Cefalo RC, McCann MF. An epidemiologic study of contraception and preeclampsia. JAMA. 1989;262(22):3143-3147.

174. Masoudian P, Nasr A, de Nanassy J, Fung-KeeFung K, Bainbridge SA, El Demellawy D. Oocyte donation pregnancies and the risk of preeclampsia or gestational hypertension: a systematic review and metaanalysis. Am JObstet Gynecol. 2016;214(3):328-339.

175. Kyrou D, Kolibianakis EM, Devroey P, Fatemi HM. Is the use of donor sperm associated with a higher incidence of preeclampsia in women who achieve pregnancy after intrauterine insemination? Fertil Steril. 2010;93(4):1124-1127.

176. Romero R, Kusanovic JP, Chaiworapongsa T, Hassan SS. Placental bed disorders in preterm labor, preterm PROM, spontaneous abortion and abruptio placentae. Best Pract Res Clin Obstet Gynaecol. 2011;25(3):313-327.

177. Brosens I, Pijnenborg R, Vercruysse L, Romero R. The "Great Obstetrical Syndromes" are associated with disorders of deep placentation. Am J Obstet Gynecol. 2011;204(3):193-201.

178. Rabaglino MB, Post Uiterweer ED, Jeyabalan A, Hogge WA, Conrad KP. Bioinformatics approach reveals evidence for impaired endometrial maturation before and during early pregnancy in women who developed preeclampsia. Hypertension. 2015;65(2):421-429.

179. Sharkey DJ, Tremellen KP, Briggs NE, Dekker
GA, Robertson SA. Seminal plasma transforming growth factor- $\beta$, activin $A$ and follistatin fluctuate within men over time. Hum Reprod. 2016;31(10):2183-2191.

180. Sharkey DJ, Tremellen KP, Briggs NE, Dekker GA, Robertson SA. Seminal plasma proinflammatory cytokines interferon- $\gamma$ (IFNG) and $\mathrm{C}-\mathrm{X}-\mathrm{C}$ motif chemokine ligand 8 (CXCL8) fluctuate over time within men. Hum Reprod. 2017;32(7):1373-1381.

181. Havrylyuk A, Chopyak V, Boyko Y, Kril I, Kurpisz M. Cytokines in the blood and semen of infertile patients. Cent Eur JImmunol.2015;40(3):337-344.

182. Robertson SA, Sharkey DJ, Tremellen KT, Dekker G. Elevated interferon- $\gamma$ in seminal plasma from male partners of women with recurrent miscarriage (abstract 809). J Soc Gynaecol Invest. 2003;10:359A.

183. Sharkey DJ, Glynn DJ, Schjenken JE, Tremellen KP, Robertson SA. Interferon- $\gamma$ inhibits seminal plasma induction of colony stimulating factor 2 in mouse and human reproductive tract epithelial cells. Biology of reproduction [published online ahead of print March 27, 2018]. Biol Reprod. https://doi.org/10.1093/biolre/ioy071.

184.Kryczek I, et al. Induction of IL-17+ T cell trafficking and development by IFN-gamma: mechanism and pathological relevance in psoriasis. JImmunol. 2008;181(7):4733-4741.

185.Zhao J, Zhao J, Perlman S. Differential effects of IL-12 on Tregs and non-Treg T cells: roles of IFN$\gamma$, IL-2 and IL-2R. PLoS One. 2012;7(9):e46241.

186. Omenetti S, Pizarro TT. The Treg/Th17 Axis: A Dynamic Balance Regulated by the Gut Microbiome. Front Immunol. 2015;6:639.

187. Sadlon T, et al. Unravelling the molecular basis for regulatory T-cell plasticity and loss of function in disease. Clin Transl Immunology. 2018;7(2):e1011.

188.Schjenken JE, Zhang B, Chan HY, Sharkey DJ, Fullston T, Robertson SA. miRNA Regulation of immune tolerance in early pregnancy. Am J Reprod Immunol. 2016;75(3):272-280.

189. Rowe JH, Ertelt JM, Aguilera MN, Farrar MA Way SS. Foxp3(+) regulatory T cell expansion required for sustaining pregnancy compromises host defense against prenatal bacterial pathogens. Cell Host Microbe. 2011;10(1):54-64.
190. Mao G, et al. Progesterone increases systemic and local uterine proportions of $\mathrm{CD} 4^{+} \mathrm{CD} 25^{+}$ Treg cells during midterm pregnancy in mice. Endocrinology. 2010;151(11):5477-5488.

191. Areia A, Vale-Pereira S, Alves V, RodriguesSantos P, Moura P, Mota-Pinto A. Membrane progesterone receptors in human regulatory $\mathrm{T}$ cells: a reality in pregnancy. BJOG. 2015;122(11):1544-1550.

192.van der Linden M, Buckingham K, Farquhar C, Kremer JA, Metwally M. Luteal phase support for assisted reproduction cycles. Cochrane Database Syst Rev. 2015;(7):CD009154.

193. Komatsu N, et al. Pathogenic conversion of Foxp $^{+} \mathrm{T}$ cells into TH17 cells in autoimmune arthritis. Nat Med. 2014;20(1):62-68.

194. Bluestone JA, Trotta E, Xu D. The therapeutic potential of regulatory $\mathrm{T}$ cells for the treatment of autoimmune disease. Expert Opin Ther Targets. 2015;19(8):1091-1103.

195. Beyer M, et al. Repression of the genome organizer SATB1 in regulatory T cells is required for suppressive function and inhibition of effector differentiation. Nat Immunol. 2011;12(9):898-907.

196. Ngalamika O, et al. Peripheral whole blood FOXP3 TSDR methylation: a potential marker in severity assessment of autoimmune diseases and chronic infections. Immunol Invest. 2015;44(2):126-136.

197. Arruvito L, Sotelo AI, Billordo A, Fainboim L. A physiological role for inducible FOXP3(+) Treg cells. Lessons from women with reproductive failure. Clin Immunol. 2010;136(3):432-441.

198.Ebina Y, Shimada S, Deguchi M, Maesawa Y, Iijima N, Yamada H. Divergence of helper, cytotoxic, and regulatory $\mathrm{T}$ cells in the decidua from miscarriage. Am J Reprod Immunol. 2016;76(3):199-204.

199.Chen X, Gan T, Liao Z, Chen S, Xiao J. Foxp3 (-/ATT) polymorphism contributes to the susceptibility of preeclampsia. PLoS One. 2013;8(4):e59696.

200.Norouzian M, Rahimzadeh M, Rajaee M, Arabpour F, Naderi N. FoxP3 gene promoter polymorphism affects susceptibility to preeclampsia. Hum Immunol. 2016;77(12):1232-1238. 